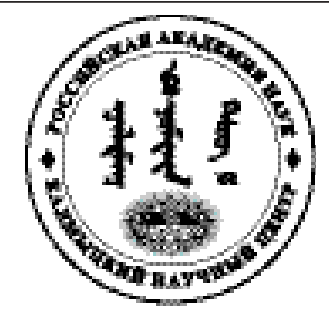

Published in the Russian Federation

Oriental Studies (Previous Name: Bulletin of the Kalmyk Institute

for Humanities of the Russian Academy of Sciences)

Has been issued as a journal since 2008

ISSN: 2619-0990; E-ISSN: 2619-1008

Vol. 13, Is. 4, pp. 927-940, 2020

DOI: $10.22162 / 2619-0990-2020-50-4-927-940$

Journal homepage: https://kigiran.elpub.ru

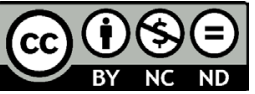

УДК 94

DOI: 10.22162/2619-0990-2020-50-4-927-940

\title{
Монголоведение в Институте востоковедения РАН: современное состояние и перспективы
}

\section{Владимир Викторович Грайворонский}

${ }^{1}$ Институт востоковедения РАН (д. 12, ул. Рождественка, 107031 Москва, Российская Федерация) доктор исторических наук, главный научный сотрудник, заведующий iD 0000-0002-1154-624X. E-mail: graiv2000@mail.ru

\author{
(C) КалмНЦ РАН, 2020 \\ (C) Грайворонский В. В., 2020
}

\begin{abstract}
Аннотация. Введение. В статье автор представил краткий общий обзор современного состояния и перспектив развития монголоведения в Институте востоковедения РАН, который недавно, в 2018 г., достойно отметил 200-летие своего создания в 1818 г. Институт востоковедения РАН сохраняет и укрепляет свои позиции одного из ведущих центров отечественного и мирового востоковедения. Цель исследования состоит в том, чтобы обобщить опыт развития монголоведения, одной из традиционных отраслей российского востоковедения, в Институте востоковедения РАН в 2010-2020 гг., охарактеризовать современное состояние и перспективы развития этого направления, показать достижения и проблемы. Материалами для исследования послужили публикации научных работ сотрудников Сектора Монголии Отдела Кореи и Монголии и других Отделов Института востоковедения РАН в 2010-2020 гг., а также материалы текущего архива Отдела. Использованы методы: исторический, хронологический, описательный, аналитический и др. Результаты исследования показывают, что, несмотря на ряд объективных и субъективных трудностей, монголоведение в Институте востоковедения РАН продолжает развиваться, разрабатываются актуальные, малоисследованные вопросы древней, средневековой, новой и новейшей истории Монголии, современного политического, социально-экономического и культурного развития Монголии и российско-монгольских отношений. В Институте востоковедения РАН, особенно в Секторе Монголии, существует острый дефицит молодых кадров-монголоведов. Без решения этой проблемы перспективы развития монголоведения в Институте востоковедения РАН не вселяют оптимизма. Институт располагает немногочисленной группой высококвалифицированных специалистов-монголоведов и других востоковедов, которые ведут научные исследования по широкому кругу направлений монголоведения (история, историография, источниковедение, выявление и публикация новых источников, памятников, архивных документов, филология, экономика, политология,
\end{abstract}


социология, культурология, буддология, номадология и др.), публикуют свои научные труды, активно сотрудничают с коллегами из однопрофильных научных и образовательных учреждений Москвы, Санкт-Петербурга, Иркутска, Улан-Удэ, Элисты, Кызыла, Владивостока и других городов России, а также с гуманитарными институтами зарубежных стран, в том числе Монголии, Китая, Японии, США, Великобритании, Германии, Франции и других стран. Хронологически обзор охватывает период 2010-2020 гг., содержит характеристику основных изменений в кадровом составе монголоведов и других востоковедов, разрабатывающих монголоведную тематику, основные направления исследований, показатели научной, научно-организационной и публикационной активности, подробно перечислены основные коллективные и индивидуальные работы монголоведов Сектора Монголии Отдела Кореи и Монголии и других отделов ИВ РАН, опубликованные в 2010-2020 гг., указаны основные проблемы развития монголоведения в контексте общего развития востоковедения, сделаны выводы и прогноз дальнейшего развития монголоведения в ИВ РАН.

Ключевые слова: ИВ РАН, монголоведение, кадры, основные направления, результаты, публикации, проблемы, прогноз

Благодарность. Материалы статьи апробированы на Международной научной онлайнконференции «Монголоведение в начале XXI в.: современное состояние и перспективы развития-ІІ», проведенной при финансовой поддержке РФФИ (проект № 20-09-22004) и частичной поддержке гранта Правительства РФ (№ 075-15-2019-1879).

Для цитирования: Грайворонский В. В. Монголоведение в Институте востоковедения РАН: современное состояние и перспективы // Oriental Studies. 2020. T. 13. № 4. C. 927-940. DOI: 10.22162/2619-0990-2020-50-4-927-940

UDC 94

DOI: $10.22162 / 2619-0990-2020-50-4-927-940$

\title{
Mongolian Studies at the Institute of Oriental Studies of the RAS: Current State and Prospects
}

\author{
Vladimir V. Grayvoronskiy ${ }^{1}$
}

${ }^{1}$ Institute of Oriental Studies of the RAS (12, Rozhdestvenka St., Moscow 107031, Russian Federation) Dr. Sc. (History), Leading Research Associate, Head

iD 0000-0002-1154-624X. E-mail: graiv2000@mail.ru

(C) KalmSC RAS, 2020

(C) Grayvoronskiy V. V., 2020

\begin{abstract}
Introduction. The paper briefly reviews the current state and prospects of Mongolian studies at the Institute of Oriental Studies (RAS) that celebrated its $200^{\text {th }}$ anniversary in 2018 . The Institute maintains and strengthens its positions as a leading national and global research center for Oriental studies. Goals. The study attempts at summarizing the Institute's 2010-2020 experiences in developing Mongolian studies as a traditional branch of Russia's Oriental studies, characterizing the present state and development prospects with due regard of actual achievements, challenges, and problems. Materials and Methods. The work analyzes scholarly publications authored by associates of the Mongolian Studies Unit (Department of Korean and Mongolian Studies) and other departments of the Institute in 2010-2020, including operating archives - through the use of historical, chronological, descriptive, analytical and other methods. Results. The study shows that despite a number of objective and subjective difficulties, associates of the Institute keep developing Mongolian studies exploring some topical and understudied issues of ancient, medieval, modern, and contemporary Mongolia; providing comprehensive insights into present-day political, socioeconomic, and cultural frameworks of Mongolia proper and Russia-Mongolia relations. Still, the Institute — and specifically
\end{abstract}


the Mongolian Studies Unit - experiences a critical shortage of qualified young Mongolists, and if the problem remains unsolved respective research perspectives should encourage no optimism. The number of highly experienced Mongolists and Orientalists that conduct research activities on a range of Mongolia-related issues (history, historiography, source studies, discoveries and publications of new sources, written monuments and archives, philology, etc.) affiliated thereto is small enough. The former publish their scholarly works and actively cooperate with colleagues from similar scientific and educational organizations of Moscow, St. Petersburg, Irkutsk, Ulan-Ude, Elista, Kyzyl, Vladivostok and other Russian cities; establish relations with foreign humanities research centers of Mongolia, China, Japan, the United States, Great Britain, Germany, France, etc. Chronologically, the review covers the period between 2010 and 2020, and characterizes key changes in staff composition; shows fundamental research trends; summarizes outcomes of scholarly, organizational and publishing activities; mentions main joint and individual monographs authored (published) by associates of the Department of Korean and Mongolian Studies in 2010-2020. The paper specifies basic development problems faced by Mongolian studies in the context of Oriental studies as such, provides conclusions and prognoses for further evolution of this research line at the Institute of Oriental Studies (RAS).

Keywords: Institute of Oriental Studies (RAS), Mongolian studies, staff, key trends, results, publications, problems, prognosis

Acknowledgements. The article was presented at the International scientific online conference 'Mongolian Studies at the Beginning of the $21^{\text {st }}$ Century: Current State and Development Prospects - II' funded by RFBR (project no. 20-09-22004) and Government of Russia (grant no. 075-15-20191879).

For citation: Grayvoronskiy V. V. Mongolian Studies at the Institute of Oriental Studies of the RAS: Current State and Prospects. Oriental Studies. 2020. Vol. 13(4): 927-940. (In Russ.) DOI: 10.22162/2619-0990-2020-50-4-927-940

\section{है}

\section{Введение}

200-летняя история Института востоковедения РАН (далее - ИВ РАН) свидетельствует, что монголоведение было и остается одним из традиционных, важных направлений российского востоковедения. ИВ РАН продолжает оставаться одним из признанных в России и во всем мире ведущих центров отечественного и мирового востоковедения, включая монголоведение. В послевоенный период в $\mathrm{CCCP}$, а затем России, помимо традиционных центров монголоведения - Москвы, Санкт-Петербурга, Казани, Иркутска, Улан-Удэ, сформировались и активно развиваются новые центры - в Новосибирске, Элисте, Кызыле, Владивостоке и др. Следует с удовлетворением отметить, что в последние годы в Республике Калмыкия быстрыми темпами развивается востоковедение, в том числе монголоведение, особенно ойратоведение, калмыковедение, общие проблемы истории, хозяйства, кочевого животноводства, языка и культуры монголоязычных народов мира.
Здесь, в Элисте успешно работают 2 монголоведных центра: Калмыцкий научный центр РАН (КалмНЦ РАН), созданный на базе Калмыцкого института гуманитарных исследований РАН, и Калмыцкий государственный университет.

ИВ РАН во многом сохраняет статус головного монголоведного учреждения в России, располагает немногочисленной группой высококвалифицированных специалистов-монголоведов и других востоковедов, которые ведут научные исследования, сотрудничают с аналогичными или близкими научными и образовательными учреждениями России - Москвы, Санкт-Петербурга, Иркутска, Улан-Удэ, Элисты и других городов, а также участвуют в международном сотрудничестве с гуманитарными институтами Академии наук Монголии, Китая, Японии, Республики Корея, США, Великобритании, Германии, Венгрии, Чехии, Польши и др. Монголоведы ИВ РАН принимают участие в деятельности Международной ассоциации монголоведения (МАМ), Российского общества 
монголоведов (президент РОМ - директор Института монголоведения, буддологии и тибетологии СО РАН, акад. Б. В. Базаров), Общества друзей Монголии (президент ОДМ - полковник ВВС в отставке В. А. Бабушкин, недавно удостоенный высокой государственной награды — ордена Дружбы народов).

Масштабы и качество научных исследований научно-исследовательского института в решающей степени зависят от наличия и уровня квалификации научных кадров.

\section{Современное состояние монголоведе- ния}

\section{Кадры}

В настоящее время основным структурным подразделением монголоведного профиля в ИВ РАН является Сектор Монголии Отдела Кореи и Монголии (руководитель Отдела - канд. ист. наук А. В. Воронцов). Кроме Сектора Монголии, различные исследования монголоведного характера ведутся также в некоторых других отделах и центрах Института (Отдел языков народов Азии и Африки, Отдел Китая, Отдел истории Востока).

За последние 10 лет в кадровом составе монголоведов и других востоковедов, занимающихся монголоведными исследованиями в ИВ РАН, произошли существенные, к сожалению, главным образом негативные изменения. Происходит неизбежный, естественный процесс старения научных сотрудников, ухода их сначала на заслуженный отдых, на пенсию, а затем с течением времени из жизни. Так, за последние 10 лет после 2010 г. Сектор Монголии понес следующие невосполнимые потери: крупный монголовед и востоковед широкого профиля, историк, экономист, политолог, международник-регионовед по Восточной Азии, преподаватель, переводчик художественной литературы, д-р полит. наук, канд. экон. наук, доцент Г. С. Яскина (2010); известный историк, большой знаток и публикатор архивных материалов по истории русско-монгольских XVII в. и советско-монгольских отношений XX в., канд. ист. наук Г. И. Слесарчук (2012); экономист, историк, дипломат, канд. экон. наук Ш. Г. Надиров (2017); известный историк и экономист, многолетний руководитель сектора Монголии, д-р ист. наук, канд. экон. наук С. К. Рощин (2019). Молодой экономист, ученик
Г. С. Яскиной, канд. экон. наук М. Б. Мещанинов перешел на постоянную работу в МИД РФ и в настоящее время работает в Посольстве РФ в Монголии. Кроме этих потерь, из монголоведов-сотрудников других отделов ИВ РАН сначала ушли на пенсию, а затем скончались известные монголоведы лингвист, канд. филол. наук М. Н. Орловская (Отдел языков, 2016); литературовед, канд. филол. наук К. Н. Яцковская (Отдел литературы, 2019), а также историки китаеведы-монголоведы А. Н. Хохлов, Е. А. Белов (Отдел Китая). В настоящее время в Отделе языков остался один монголовед д-р филол. наук С. А. Крылов. В Отделе литературы народов Азии и Отделе сравнительного культуроведения отсутствуют специалисты по литературе и культуре монгольских народов.

В настоящее время в Секторе Монголии работают 6 научных сотрудников, в том числе 4 штатных (д-р ист. наук В. В. Грайворонский; д-р ист. наук К. В. Орлова; д-р ист. наук С. Л. Кузьмин; канд. ист. наук Е. В. Бойкова); д-р ист. наук М. И. Гольман и д-р филол. наук, проф. РГГУ А. Д. Цендина.

В 2017 г. поредевшие ряды монголоведов Сектора Монголии пополнил д-р ист. наук, канд. биол. наук С. Л. Кузьмин, который в течение нескольких лет работал совместителем, а затем успешно защитил докторскую диссертацию по истории взаимоотношений буддизма и государства в период становления государственной независимости Монголии в первой половине XX в. и стал одним из ведущих сотрудников Сектора и Института. С. Л. Кузьмин активно и плодотворно работает не только в области монголоведения, но и тибетологии и буддологии.

С середины 2017 г. до недавнего времени (до середины сентября с. г.) в Институте работал д-р полит. наук А. С. Железняков в качестве заместителя директора по науке и куратора Отдела Кореи и Монголии. В ИВ РАН он продолжал разрабатывать проблематику монгольской цивилизации, о чем свидетельствуют его недавние публикации, в том числе монография «Монгольская цивилизация. История и современность. Теоретическое обоснование атласа» [Железняков 2016] и подготовленный к печати иллюстрированный исторический альбом «Лики монгольской цивилизации». 
В 2017 г. по инициативе А. С. Железнякова в Институте был создан Центр политологических и социологических исследований Внутренней Азии, в 2018 г. в рамках международного научного конгресса, посвященного 200-летию ИВ РАН, была организована международная конференция «Монгольская цивилизация в фокусе российского востоковедения», в печати находится сборник материалов конференции.

Аспиранты в Отделе Кореи и Монголии отсутствуют уже несколько лет. Современная молодежь, в том числе монголоведы-выпускники вузов Института стран Азии и Африки при МГУ, МГИМО МИД РФ, РГГУ, неохотно идут в науку, в том числе в монголоведение. В Институте стран Востока, который размещается в здании ИВ РАН, монголоведение не относится к числу привлекательных специализаций. Такое состояние во многом связано с общим положением в российской науке, Академии наук и других институтах.

\section{Основные направления исследований}

Судя по публикациям трудов сотрудников ИВ РАН за последние годы, монголоведные исследования с разной степенью охвата и глубины велись и ведутся по следующим основным направлениям: источниковедение; историография; публикация новых источников, памятников, архивных документов; средневековая, новая и новейшая история Монголии; история Чингис-хана и Монгольской империи; история трех революций в Монголии в XX в., история буддизма и буддийской церкви в Монголии, ее взаимоотношений с государством в первой половине XX в.; жизнь и деятельность видных политических деятелей Монголии первой половины XX в.; вклад русских военных исследователей Монголии в конце XIX - начале XX вв.; внутренняя и внешняя политика МНР / Монголии; ход и результаты постсоциалистической политической и социально-экономической модернизации Монголии; политическая история; международное положение и внешняя политика современной Монголии; история и современные российско-монгольские отношения; политические и торгово-экономические отношения в «треугольнике» Россия-Монголия-Китай; языки и литература Монголии и монголоязычных наро- дов России (буряты, калмыки); выявление, изучение и публикация археологических, письменных исторических и литературных памятников; издание Собрания сочинений акад. Б. Я. Владимирцова; история и историография отечественного и мирового монголоведения в России, на Западе, в США и Европе; составление библиографий работ отечественных монголоведов и др.

В работе сектора Монголии первостепенное внимание уделяется изучению хода и результатов политических, экономических, социальных и других реформ, которые осуществляются в Монголии после 1990 г., актуальным вопросам истории и современного развития двусторонних российско-монгольских, а также трехсторонних отношений между Россией, Монголией и Китаем. Руководитель Отдела Кореи и Монголии А. В. Воронцов и другие сотрудники В. В. Грайворонский, М. И. Гольман, Е. В. Бойкова принимают участие в трехсторонних научных форумах экспертов Think Tank России, Китая и Монголии, которые поочередно проводятся в этих странах.

Используются новые формы научного сотрудничества между ИВ РАН и региональными монголоведческими центрами. Так, в апреле 2017 г. по инициативе ректора КалмГУ, канд. пед. наук Бадмы Катиновича Салаева и при поддержке дирекции ИВ РАН впервые в истории Института были успешно организованы и проведены «Дни Института востоковедения РАН в КалмГУ», в которых приняла участие группа ведущих сотрудников Института, в том числе канд. ист. наук Н. Г. Романова, д-р ист. наук, проф. А. Ш. Кадырбаев, д-р ист. наук В. В. Грайворонский, д-р полит. наук А. С. Железняков, д-р ист. наук К. В. Орлова. Следует отметить, что в Элисте делегации ИВ РАН были оказаны исключительно теплый прием и гостеприимство, насыщенная программа была выполнена на высоком научном и организационном уровне. Достигнуты договоренности о продолжении сотрудничества в разнообразных формах. К. В. Орлова принимает активное участие в организации и проведении совместных экспедиций по изучению буддийских традиций на территории Западной Монголии и Калмыкии, в написании коллективных монографий, в том числе «Буддийская традиция в Калмыкии и Западной Монголии: сакраль- 
ные объекты» [Буддийская традиция 2015] и «Трансграничная культура: очерки сравнительно-сопоставительного исследования традиций западных монголов и калмыков» [Трансграничная культура 2016].

\section{Публикации}

В последние годы (2010-2020 гг.) сотрудниками сектора Монголии подготовлен и опубликован ряд новых, интересных коллективных и индивидуальных работ. Крупным событием в истории отечественного и мирового монголоведения стал выход в свет в 2016 г. последнего, четвертого, тома Собрания сочинений выдающегося российского монголоведа акад. Б. Я. Владимирцова «Письма. Неизданное» в серии «Классики российского востоковедения» [Владимирцов 2016]. В этом большая заслуга А. Д. Цендиной, одного из составителей и ответственного редактора тома.

В 2019 г. в истории российского монголоведения и российско-монгольских отношений произошло еще одно важное событие. Вышел из печати сборник «Монголия в документах из архивов ФСБ России. 1922 1936 гг.», подготовленный сотрудниками сектора Монголии ИВ РАН в кооперации с сотрудниками Центрального архива ФСБ [Монголия в документах 2019].

Тем самым была продолжена давняя традиция публикации новых архивных документов по истории русско-монгольских и советско-монгольских отношений. Особая актуальность и ценность этого сборника состоит в том, что, во-первых, это вообще первая в истории публикация документов о Монголии, хранящихся в архивах этого ведомства, которое сыграло особую роль в истории России и Монголии, а, во-вторых, в нем впервые опубликованы 163 новых, ранее засекреченных документа из Центрального архива ФСБ и архива УФСБ Омской области. Документы охватывают все основные сферы советско-монгольских отношений (политика, национальная безопасность, оборона, торговля, экономика, культура, религия, международные отношения). Тем самым в научный оборот введен крупный массив новых, важных, ранее недоступных архивных документов, которые проливают дополнительный свет на характер и особенности советско-монгольских отношений в указанный период.
В 2011 г. совместно с Институтом международных отношений АН Монголии была подготовлена и опубликована коллективная международная монография «Россия и Монголия на пути стратегического партнерства» [Россия и Монголия 2011].

В 2010-2020 гг. сотрудники сектора Монголии подготовили и опубликовали ряд индивидуальных монографий и сборников трудов, в том числе: М. И. Гольман — «Современная Монголия в оценках западных авторов» [Гольман 2010]; «Сборник избранных статей и докладов» [Гольман 2014], монография «Монголия глазами монголоведа (60-70-е годы XX века)» [Гольман 2019].

Была опубликована очередная, к сожалению, последняя монография С. К. Рощина «Д. Сухэ-Батор - национальный герой Монголии. Штрихи портрета» [Рощин 2011]. Вышли также монографии В. В. Грайворонского «Изменения в уровне жизни населения Бурятии (Россия), Монголии и Внутренней Монголии (Китай) в конце XX - начале XXI вв.» [Грайворонский 2014], «Монголия в начале XXI в. (политика, экономика, общество)» [Грайворонский 2017]; К. В. Орловой - «История захчинского буддийского монастыря (предисловие, перевод, комментарий, факсимиле)» [Орлова 2012]; «Христианизация калмыков в контексте внутренней и внешней политики России (середина XVII - начало XX вв.)» [Орлова 2018]; Е. В. Бойковой - «Российские военные исследователи Монголии (вторая половина X1X - начало XX вв.)» [Бойкова 2016] .

С. Л. Кузьмин самостоятельно и в сотрудничестве с российскими и монгольскими коллегами опубликовал несколько исследований и работ по малоисследованным, ранее «непопулярным» темам, в том числе «Вооруженное восстание в Монголии в 1932 г.» [Кузьмин, Оюунчимэг 2015], «Теократическая государственность и буддийская церковь Монголии в начале XX в.» [Кузьмин 2016], выступил ответственным редактором русского издания монографии известного монгольского историка, лауреата Государственной премии Монголии О. Батсайхана «Последний великий хан Монголии Богдо Джебцзундамба-хутухта VIII. Жизнь и легенды» [Батсайхан 2018], а также русского издания воспоминаний известного монгольского религиозного де- 
ятеля Дилова-хутухты «Дилова-хутухта в Монголии. Политические мемуары и автобиография перевоплощения буддийского ламы» [Дилова 2018] и др.

Особо следует отметить большую, многолетнюю и плодотворную научно-исследовательскую и преподавательскую деятельность А. Д. Цендиной, которая самостоятельно и в сотрудничестве с монгольскими и российскими коллегами опубликовала под грифом ИВ РАН ряд новых, оригинальных, ценных работ, в том числе «Образцы письменной традиции Северной Монголии: алфавиты, транскрипции, языки (XVIIXIX вв.)» [Цендина, Отгонбаатар 2014], «Желтая история (Шара туджи)» [Цендина 2017], «Жизнь, отраженная в текстах. Повседневность и культура Северной Монголии (XVII-XX в.)» (работа выполнена в 2018 г., но пока не издана); Каталог монгольских рукописей и ксилографов квартиры-музея Ц. Дамдинсурэна [Билгуудэй, Отгонбаатар, Цендина 2018].

Трудно переоценить огромное научное, образовательное, культурное и политическое значение издания Каталога монгольских рукописей и ксилографов квартиры-музея академика Ц. Дамдинсурэна в Улан-Баторе, первого издания подобного рода, ставшего блестящим итогом многолетнего, целенаправленного, совместного труда сплоченного коллектива составителей каталога. Благодаря изданию этого каталога квартира-музей Ц. Дамдинсурэна становится новым, самостоятельным центром мирового монголоведения. Тем самым, А. Д. Цендина, дочь, ученица, помощник, последователь и продолжатель дела своего отца - академика Ц. Дамдинсурэна в высшей степени достойно продолжила дело, которому он посвятил большую часть своей жизни.

В 2017 г. две ранее изданные книги А. Д. Цендиной, в том числе «Удивительные записки, легенда о путешествии вокруг света» Агвана Доржиева» [Удивительные записки 2017] и «История Эрдэни дзу» были переведены на старомонгольский язык и изданы в Хух-хото (Внутренняя Монголия, KHP) [Erdeni juu-yin 2017].

В том же 2017 г. Международная ассоциация монголоведения впервые в истории мирового монголоведения провела своеобразный конкурс на определение лучшего зарубежного монголоведа года и признала А. Д. Цендину лучшим монголоведом мира 2017 г. с вручением ей оригинального приза и денежной премии. Это важное событие следует рассматривать как высокое признание не только личных заслуг талантливого, целеустремленного и неутомимого исследователя Анны Дамдиновны Цендиной, но также и как признание заслуг российского монголоведения в целом.

Некоторые монографии С. К. Рощина, М. И. Гольмана, А. Д. Цендиной, С. Л. Кузьмина переведены на монгольский язык и изданы в Монголии при поддержке Института истории и археологии АН Монголии (директор - д-р ист. наук, проф. С. Чулуун, ученый секретарь - канд. ист. наук Н. Хишигт), Института языка и литературы АН Монголии (директор - канд. филол. наук, доцент Г. Билгуудэй), за что коллектив Сектора Монголии ИВ РАН выражает им искреннюю признательность и благодарность.

В 2010-2020 гг. усилиями главным образом сотрудников Сектора Монголии были организованы и проведены около 10 международных, общероссийских, межинститутских конференций и симпозиумов, материалы которых легли в основу опубликованных и находящихся в издательстве сборников: «Российское монголоведение» (Бюллетень № 6 2012) [Российское монголоведение 2012], «Россия, Китай и Монголия: вместе навстречу вызовам современности» [Россия, Китай 2013]; «Г. И. Слесарчук. Избранные статьи» [Слесарчук 2013], «Халхин-Гол: взгляд на события из XXI века» [Халхин-гол 2013], «Б. Ширендыб и С. Д. Дылыков в воспоминаниях родственников, коллег и друзей (К 100-летию со дня рождения Б. Ширендыба и С. Д. Дылыкова)» [Б. Ширендыб 2014]; «Я рад, что стал монголоведом. К 85-летию С. К. Рощина» [Я рад 2015], «Россия - Монголия: история, вызовы XXI в., перспективы» [Россия - Монголия 2017], «Владимирцовские чтения - VI» [Владимирцовские чтения 2017], «Монгольская цивилизация в фокусе российского востоковедения», «Победа на p. Халхин-гол (1939): в поисках исторической истины (решение об издании обеих работ будет принято 23.12.2020 на заседании редакционно-издательского совета ИВ РАН) и др. 
Сотрудники Сектора Монголии участвуют в подготовке молодых востоковедов и монголоведов, дают консультации, выступают в качестве официальных оппонентов на защитах кандидатских и докторских диссертаций российских и монгольских аспирантов, докторантов и соискателей. Д-р филол. наук, проф. А. Д. Цендина в течение многих лет возглавляет кафедру монгольско-тибетской филологии в РГГУ.

Монголоведы Института принимают активное участие во многих международных, общероссийских, межинститутских и институтских научных мероприятиях, в том числе в международных конгрессах монголоведов в Улан-Баторе, конференциях и симпозиумах в Москве, Санкт-Петербурге, Улан-Удэ, Элисте и за рубежом (Монголия, КНР, Япония, США, Германия и др.).

Монголоведы ИВ РАН выступают в качестве экспертов, дают свои комментарии СМИ о текущих событиях в Монголии и российско-монгольских отношениях (К. В. Орлова, В.В.Грайворонский, М. И. Гольман, С. Л. Кузьмин, А. Д. Цендина). М. И. Гольман регулярно публикует статьи о событиях в Монголии в интернет-журнале ИВ РАН «Новое восточное обозрение».

\section{Международное сотрудничество}

Монголоведы ИВ РАН традиционно сотрудничают с Институтом истории и этнографии, Институтом международных отношений, Институтом языка и литературы АН Монголии, Институтом стратегических исследований АН и Совета национальной безопасности Монголии, Международной ассоциацией монголоведов, Международным институтом кочевых цивилизаций (штаб-квартира в Улан-Баторе) и др. Особо следует выделить тесное и плодотворное сотрудничество с Институтом истории и этнографии АНM, который неоднократно оказывал помощь в организации совместных конференций, публикации совместных работ, а также индивидуальных работ монголоведов - С. К. Рощина, М. И. Гольмана, Г. И. Слесарчук, С. Л. Кузьмина.

По давней традиции монголоведная тематика, преимущественно связанная с историей Китая, Монголии, Монгольской империи, стран Центральной Азии, местом и ролью кочевых народов в мировой истории, в той или иной степени разрабатывается в некоторых других отделах ИВ РАН, в том числе в Отделе Китая и Отделе истории Востока. Так, в Отделе истории Востока его руководитель, известный тюрколог, проф. Д. Д. Васильев в течение многих лет успешно занимается исследованием тюркских памятников на территории Монголии [Baсильев 1978; Васильев 1983; Васильев, Горелик, Кляшторный 1993; Васильев 1995].

А. Ш. Кадырбаев специализируется на истории Юаньской (Монгольской) империи в Китае, ее взаимоотношений с народами Центральной Азии [Кадырбаев 1984; Султанов и др. 2015; и др.].

Ю. И. Дробышев на примере монгольских и тюркских скотоводов-кочевников Центральной Азии активно исследует актуальную экологическую тематику, историю взаимоотношений кочевых народов с окружающей средой, роль климатического фактора в политической истории Монголии и Центральной Азии, проблемы сакрализации верховной власти у кочевых народов [Дробышев 2014; Дробышев 2018; и др.].

Д. М. Тимохин изучает историю монгольских завоеваний в Центральной Азии, на Кавказе, в России [Тимохин 2013; и др.]

В Отделе истории Востока работает канд. ист. наук Б. У. Китинов, который специализируется на изучении истории буддизма у ойратов (западных монголов), подготовил и успешно защитил докторскую диссертацию [Китинов 2020; и др.].

Заведующий сектором средневековой и новой истории Китая канд. ист. наук С. В. Дмитриев самостоятельно и в кооперации с С. Л. Кузьминым разрабатывает отдельные малоисследованные, дискуссионные вопросы древней, средневековой, новой и новейшей истории Китая и Монголии, китайско-монгольских отношений в конце XIX - начале XX вв. [Дмитриев 2003; Дмитриев 2005; Дмитриев 2009; и др.]

Руководитель Центра японских исследований д-р ист. наук, проф. Е. Л. Катасонова, один из авторитетных специалистов по истории вооруженного конфликта в районе p. Халхин-гол в 1939 г., активно сотрудничает с монголоведами в организации конференций, посвященных памятным датам этих событий, в частности, международной научной конференции, посвященной 80-летию победы советско-монгольских войск над японо-маньчжурскими войсками, в ко- 
торой приняли участие многие ведущие гражданские и военные специалисты из России, Монголии, Японии и Китая [Катасонова 2009; Катасонова 2013; Катасонова 2014].

\section{Проблемы и перспективы}

По нашему мнению, основные проблемы современного развития монголоведения состоят в следующем:

1) не разработана четко сформулированная концепция и программа развития отечественного востоковедения, включая монголоведение, в увязке с актуальными и стратегическими целями и задачами внешней политики России и потребностями отечественной науки;

2) недостаточное финансирование научных исследований, в том числе для публикации уже готовых работ, организации международных и национальных конференций, симпозиумов, «круглых столов» в России, для участия российских ученых в международных научных конференциях за рубежом, для осуществления активного, взаимовыгодного международного научного сотрудничества с соответствующими институтами Монголии, Китая, Японии, США, стран ЕС и др.;

3) идет естественный процесс старения и сокращения кадров высококвалифицированных монголоведов старшего поколения, отсутствует молодая смена, аспиранты, происходит очередной разрыв преемственности между старшим и молодым поколениями монголоведов, отсутствует система целенаправленной подготовки молодых монголоведов, у молодых монголоведов-выпускников Института стран Азии и Африки при Московском государственном университете, Российском государственном гуманитарном университете и Московском государственном институте международных отношений МИД РФ нет стимулов и желания идти в науку;

4) институт испытывает дефицит специалистов по таким актуальным направлениям, как политические, социально-экономические и другие проблемы развития современной Монголии, история и современные отношения между Россией, Монголией и Китаем, экономика современной Монголии и ее место в региональной интеграции, средневековая, новая и новейшая история Монголии, эпоха Чингис-хана, Монголь- ской империи, Золотой Орды, политология, филология, культурология, публикация архивных документов и др.;

5) недостаточная координация исследований между основными монголоведными академическими и образовательными центрами в масштабе России.

\section{Заключение}

Резюмируя вышесказанное, следует сделать несколько выводов. Во-первых, точка зрения некоторых российских, монгольских и других зарубежных коллег о том, что монголоведение в Институте востоковедения РАН «переживает кризис», «постепенно умирает», явно преувеличена и не соответствует действительности. Монголоведение хоть и не процветает, но продолжает развиваться, адаптируясь к существующим финансовым, кадровым и организационным условиям, стремится находиться на современном мировом уровне. Несмотря на ряд объективных и субъективных трудностей, монголоведы и другие востоковеды, разрабатывающие монголоведную тематику, продолжают активно работать по избранным направлениям и утвержденным планам, пишут и публикуют новые, оригинальные, интересные труды по малоисследованным и актуальным проблемам монголоведения, вводят в научный оборот новые источники, памятники, архивные документы, изучают и анализируют опыт трансформации политической, экономической, социальной систем и культурной жизни современной Монголии.

Во-вторых, в условиях пересмотра прежней, советской, марксистско-ленинской концепции истории Монголии и российско-монгольских отношений в XX в., перед российскими монголоведами, историками, политологами, филологами, экономистами, культурологами стоит актуальная задача принять участие в создании обновленной, более полной, более объективной истории российско-монгольских отношений в XX в. с целью восстановить историческую правду, раскрыть и показать реальную позитивную роль СССР / России в истории Монголии XX в.

В-третьих, монголоведы ИВ РАН заинтересованы в продолжении традиционного научного сотрудничества со своими традиционными и новыми однопрофильными, 
родственными академическими институтами и вузами России.

В-четвертых, монголоведы ИВ РАН также заинтересованы в сохранении и развитии традиционного, плодотворного сотрудничества с зарубежными коллегами Монголии, Китая, Японии, Республики Корея, США, Великобритании, Франции, Германии и других стран, в первую очередь с Между-

\section{Литература}

Буддийская традиция 2015 - Буддийская традиция в Калмыкии и Западной Монголии: сакральные объекты / Э. П. Бакаева, К. В. Орлова, Н. Хишигт, Ц. Энхчимэг. М.: Наука; Вост. лит., 2015. 238 с.

Батсайхан 2018 - Батсайхан $О$. Последний великий хан Монголии Богдо Джебцзундамба-хутухта VIII. Жизнь и легенды / отв. ред. русск. изд. С. Л. Кузьмин. М.: КМК, 2018. $406 \mathrm{c.}$

Билгуудэй, Отгонбаатар, Цендина 2018 - Билгуудэй Г., Отгонбаатар Р., Цендина $A$. Каталог монгольских рукописей и ксилографов квартиры музея Ц. Дамдинсурэна / доп. транслит., индексы и ред. А. Туранской, Н. Ямпольской; ред. С. Байгалсайхан. Улан-Батор, 2018. 620 с. (На монг. яз.)

Бойкова 2016 - Бойкова E. В. Российские военные исследователи Монголии (вторая половина X1X - начало XX вв.). М.: ИВ РАН, 2016. $262 \mathrm{c}$.

Б. Ширендыб 2014 - Б. Ширендыб и С. Д. Дылыков в воспоминаниях родственников, коллег и друзей (К 100-летию со дня рождения Б. Ширендыба и С. Д. Дылыкова) / сост., отв. ред. В. В. Грайворонский). М.: ИВ РАН, 2014. 192 c.

Васильев 1978 - Васильев Д. Д. Тюркская руническая надпись. Хэнтэй 1 // Советская этнография. 1978. № 3. С. 149-151.

Васильев 1983 - Васильев Д. Д. Корпус тюркских рунических памятников бассейна Енисея. М.: Наука, 1983. 128 с.

Васильев, Горелик, Кляшторный 1993 - Baсильев Д. Д., Горелик М. В., Кляшторный $C$. Г. Формирование имперских культур в государствах, созданных кочевниками Евразии // Из истории Золотой Орды / отв. ред. Г. Ф. Валеева-Сулейманова. Казань: фонд им. М. Султангалиева, 1993. С. 33-44.

Васильев 1995 - Васильев Д. Д. Orhun. Атлас древностей Монголии, изданный В. В. Радловым / сост., перев. на тур. яз., предисл. народной ассоциацией монголоведения, Институтом истории и этнографии, Институтом международных отношений, Институтом языка и литературы АН Монголии, Институтом стратегических исследований, Международным институтом ЮНЕСКО по изучению кочевых цивилизаций (Улан-Батор), Монгольский государственный университет и др.

(Памяти В. В. Радлова). Анкара: ТИКА, 1995. 80 c. (In folio).

Владимирцов 2016 - Владимирицов Б. Я. Письма. Неизданное / сост.: Г. И. Слесарчук, А. Д. Цендина; отв. ред. А. Д. Цендина. М.: Наука; Вост. лит., 2016. 390 с.

Владимирцовские чтения 2017 - Владимирцовские чтения - VI / сост.-ред. К. В. Орлова, отв. ред. В. В. Грайворонский. М.: ИВ РАН, 2017. $272 \mathrm{c}$

Гольман 2010 - Гольман М. И. Современная Монголия в оценках западных авторов. М.: ИВ РАН, 2010. 190 с.

Гольман 2014 - Гольман М. И. Избранные статьи и доклады. Улаанбаатар: Соёмбо, 2014. $322 \mathrm{c}$.

Гольман 2019 - Гольман М. И. Монголия глазами монголоведа (60-70-е годы XX века). М.: ИВ РАН, 2019. 285 c.

Грайворонский 2014 - Грайворонский В. В. Изменения в уровне жизни населения Бурятии (Россия), Монголии и Внутренней Монголии (Китай) в конце XX - начале XXI вв. / ИВ РАН. Лос-Анжелес; Улан-Батор: Агиймаa, 2014. 284 c.

Грайворонский 2017 - Грайворонский В. В. Монголия в начале XXI в. (политика, экономика, общество). М.: ИВ РАН, 2017. 352 с.

Дилова 2018 - Дилова-хутухта в Монголии. Политические мемуары и автобиография перевоплощения буддийского ламы / отв. ред. русск. изд. С. Л. Кузьмин. М.: Фонд «Сохраним Тибет», 2018. 352 с.

Дмитриев 2003 - Дмитриев С. В. Монголы в XIII веке - мировая империя и проблемы сохранения национально-культурной идентичности // Этнокультурное образование: совершенствование подготовки специалистов в области традиционных культур. Мат-лы IV междунар. науч. симпозиума (г. Улан-Удэ, 25-28 сентября 2003 г.). Т. 3. Улан-Удэ: ИПК ВСГАКИ, 2003. С. 296-304. Дмитриев 2005 - Дмитриев С. В. Самый вли- 
ятельный христианин монгольской империи. Проблемы реконструкции биографии иноземца на монгольской службе // XXXV науч. конф. «Общество и государство в Китае». М.: ИВ РАН, 2005. С. 173-176.

Дмитриев 2009 - Дмитриев С. В. К вопросу о Каракоруме // XXXIX науч. конф. «Общество и государство в Китае». Ученые записки Отдела Китая. Вып. І. М.: ИВ РАН, 2009. C. $76-100$.

Дробышев 2014 - Дробышев Ю. И. Человек и природа в кочевых обществах Центральной Азии (III в. до н. э. - XIV в. н. э.) / отв. ред. Д. Д. Васильев, науч. ред. Л. И. Лебедева; Ин-т востоковедения РАН. М.: МБА, 2014. $605 \mathrm{c}$.

Дробышев 2018 - Дробышев Ю. И. Климат и ханы: роль климатического фактора в политической истории Центральной Азии. М.: ИВ РАН, 2018. 264 c.

Железняков 2016 - Железняков А. С. Монгольская цивилизация. История и современность. Теоретическое обоснование атласа. М.: Весь мир, 2016. 288 с.

Кадырбаев 1984 - Кадырбаев А. Ш. «Юаньши» как источник по истории кераитов и найманов // Письменные памятники Востока: Историко-филологические исследования. 1976-1977. М.: Наука, ГРВЛ, 1984. С. 254-259.

Катасонова 2009 - Катасонова Е. Л. Халхин-Гол: 70 лет спустя // Япония 2009. Ежегодник. М.: ИВ РАН, 2009. С. 271-293.

Катасонова 2013 - Катасонова Е. Л. Японские военнопленные в СССР: 1945-1956. Сб. док. Совместно с Гавриловым В. А. М.: Фонд «Демократия», 2013. 779 с.

Катасонова 2014 - Катасонова Е. Л. Необъявленная война: к 75-летию событий на Халхин-Голе // Актуальные проблемы современной Японии. Вып. 28 / гл. ред. В. О. Кистанов. М.: ИДВ РАН, 2014. С. 189-200.

Китинов 2020 - Китинов Б. У. Буддийский фактор в политической и этнической истории ойратов (середина XVв. - 1771 г.): автореф. дис. ... д-ра ист. наук. М., 2020. 53 с.

Кузьмин, Оюунчимэг $2015-$ Кузьмин С. Л., Оюунчимэг Ж. Вооруженное восстание в Монголии в 1932 г. М.: ИВ РАН; МБА, 2015. $138 \mathrm{c}$.

Кузьмин $2016-$ Кузьмин С. Л. Теократическая государственность и буддийская церковь Монголии в начале XX в. М.: КМК, 2016. $496 \mathrm{c}$.
Монголия в документах 2019 - Монголия в документах из архивов ФСБ России. 19221936 гг. / науч. ред. В. В. Наумкин, отв. ред. К. В. Орлова, В. В. Грайворонский; Ин-т востоковедения РАН. М.: ИВ РАН, 2019. $528 \mathrm{c}$.

Орлова 2012 - Орлова К. В. История захчинского буддийского монастыря (предисл., перев., коммент., факсимиле рукописи). М.: ИВ РАН, 2012. $202 \mathrm{c}$.

Орлова 2018 - Орлова К. В. Христианизация калмыков в контексте внутренней и внешней политики России (середина XVII - начало ХХ вв.). М.: ИВ РАН, 2018. 400 с.

Российское монголоведение 2012 - Российское монголоведение. Бюллетень № 6 / сост. К. В. Орлова, отв. ред. В. В. Грайворонский. М.: ИВ РАН, 2012. $281 \mathrm{c}$.

Россия - Монголия 2017 - Россия - Монголия: история, вызовы XXI в., перспективы. Матлы междунар. науч. конф., посвященной 95-летию установления дипломатических отношений между Россией и Монголией (г. Москва, ИВ РАН, 13-14 октября 2016 г.) / ИВ РАН; Ин-т истории и археологии АН Монголии; Ин-т социологии РАН. Улан-БаTop: ADMON. 2017. 250 c.

Россия и Монголия 2011 - Россия и Монголия на пути стратегического партнерства / отв. ред.: Р. Б. Рыбаков, Л. Хайсандай. ИВ РАН; Ин-т междунар. исследов. АН Монголии. М.: ИВ РАН, 2011. 440 с.

Россия, Китай 2013 - Россия, Китай и Монголия: вместе навстречу вызовам современности. Мат-лы III междунар. науч. форума / отв. ред. Е. В. Бойкова. М.: ИВ РАН, 2013. $224 \mathrm{c}$.

Рощин 2011 - Рощчин С. К. Д. Сухэ-Батор национальный герой Монголии. Штрихи портрета. Улан-Батор: Сэлэнгэ пресс, 2011. 280 с. (На рус. и монг. яз.)

Слесарчук 2013 - Слесарчук Г. И. Статьи разных лет / ред. С. Чулуун, К. В. Орлова, А. Д. Цендина. Улан-Батор: Соёмбо принтинг ХХК, 2013. 220 с.

Султанов и др. 2015 - Султанов Т. И., Сblздыкова Ж. С., Кадырбаев А. Ш., Зайщев И. В. История Центральной Азии: уч. пособ. Т. 1. 2-е изд., доп. М.: Изд-во Моск. Гуман. Унта, $2015.360 \mathrm{c}$.

Тимохин 2013 - Тимохин Д. М. Соперник Чингиз-хана: хорезмшах Джелал-ад-Дин Манкбурны, личность и эпоха / отв. ред. А. Ш. Кадырбаев. М.: МБА, 2013. 268 с. 
Трансграничная культура 2016 - Бакаева Э. П., Орлова К. В., Музраева Д. Н. и др Трансграничная культура: очерки сравнительно-сопоставительного исследования традиций западных монголов и калмыков». Элиста: ЗАОр «НПП ,Джангар“». 2016. 452 с.

Удивительные записки 2017 - «Удивительные записки, легенда о путешествии вокруг света» Агвана Доржиева) [Oros] Čendin-a sudulun emkidkebe (Публикация Цендиной А. Д. [Россия] // Mongүol sudulul-un

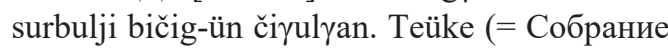
письменных источников по изучению $\mathrm{MoH}$ -

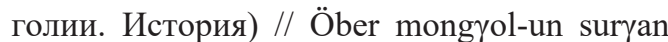
kümüjil-ün keblel-ün qoriy-a. Хух-хото: Педагог. изд-во Внутр. Монголии, 2017. 133 с.

Халхин-гол 2013 - Халхин-Гол: взгляд на события из XXI века / сост.-ред. Е. В. Бойкова. М.: ИВ РАН, 2013. 156 c.

Цендина 2017 - Желтая история (Шара туджи) / пер. с монг., транслит., введ. и коммент.

\section{References}

Bakaeva E. P., Orlova K. V., Khishigt N., Enkhchimeg Ts. Buddhist Tradition in Kalmykia and Western Mongolia: Sacred Objects. Moscow: Nauka; Vostochnaya Literatura, 2015. 238 p. (In Russ.)

Bakaeva E. P., Orlova K. V., Muzraeva D. N. et al. Cross-Border Culture: Comparative Studies in Traditions of Western Mongols and Kalmyks. Elista: Dzhangar, 2016. 452 p. (In Russ.)

Batsaikhan O. $8^{\text {th }}$ Jebtsundamba Khutukhtu. The Last Great Khan of Mongolia: Life and Legends. S. Kuzmin (ed.). Moscow: KMK, 2018. 406 p. (In Russ.)

Bilguudey G., Otgonbaatar R., Tsendina A. Memorial House of Ts. Damdinsüren: A Catalogue of Mongolian Manuscripts and Xylographs. A. Turanskaya, N. Yampolskaya (translit., indices, ed.); S. Baigalsaikhan (ed.). Ulaanbaatar, 2018. 620 p. (In Mong.)

Boykova E. V. (comp.), Chuluun S. (ed.) 'I Am Glad to Have Become a Mongolist': Celebrating S. K. Roshchin's 85 ${ }^{\text {th }}$ Anniversary of Birth. Institute of Oriental Studies (RAS); Institute of History and Archaeology (Mongolian Academy of Sciences). Moscow; Ulaanbaatar, 2015. 296 p. (In Russ.)

Boykova E. V. (comp., ed.) Khalkhin-Gol: A View from the $21^{\text {st }}$ Century. Moscow: Institute of Oriental Studies (RAS), 2013. 156 p. (In Russ.)
А. Д. Цендиной. Факсимиле рукописи (список А) // Памятники письменности Востока. CXLVII. М.: Наука; Вост. лит., 2017. 406 с.

Цендина, Отгонбаатар 2014 - Цендина А. Д., Отгонбаатар $P$. Образцы письменной традиции Северной Монголии: алфавиты, транскрипции, языки (XVII-XIX вв.). М.: ИВ РАН, 2014. 240 c.

Я рад 2015 - «Я рад, что стал монголоведом. К 85-летию С. К. Рощина» / ИВ РАН; ИИА АН Монголии; сост. Е. В. Бойкова, отв. ред. С. Чулуун. М.; Улан-Батор, 2015. 296 с.

Erdeni juu-yin 2017 — Erdeni juu-yin teüke (= История Эрдэни дзу). [Oros] Čendin-a sudulun emkidkebe (Публикация Цендиной А. Д. // Mongrol sudulul-un surbulji bičig-ün čipulyan. Teüke (= Собрание письменных источников по изучению Монголии. История) // Öber mongyol-un suryan kümüjil-ün keblel-ün qoriy-a. Хух-хото: Педагог. изд-во Внутр. Монголии, 2017. 276 с.

Boykova E. V. (ed.) Russia, China, and Mongolia: Together Towards Contemporary Challenges. Forum Proceedings. Moscow: Institute of Oriental Studies (RAS), 2013. 224 p. (In Russ.)

Boykova E. V. Exploring Mongolia: Russian Military Researchers, Mid-19 $9^{\text {th }}$ to Early $20^{\text {th }}$ Centuries. Moscow: Institute of Oriental Studies (RAS), 2016. 262 p. (In Russ.)

Dmitriev S. V. Mongols in the $13^{\text {th }}$ century: the World Empire and problems of retaining ethnocultural identity. In: Ethnocultural Education. Improving Training of Specialists in Traditional Cultures. Symposium Proceedings (Ulan-Ude; September 25-28, 2003). Vol. 3. Ulan-Ude: East-Siberian State Institute of Culture, 2003. Pp. 296-304. (In Russ.)

Dmitriev S. V. The issue of Karakorum revisited. In: Society and State in China. Conference Proceedings. Ser.: Department of China Scholarly Notes. Vol. I. Moscow: Institute of Oriental Studies (RAS), 2009. Pp. 76-100. (In Russ.)

Dmitriev S. V. The most influential Christian in the Mongol Empire: problems of reconstructing a foreigner's biography. In: Svistunova N. P. (comp., ed.) Society and State in China. Conference Proceedings. Moscow: Institute of Oriental Studies (RAS), 2005. Pp. 173-176. (In Russ.) 
Dorzhiev A. Magnificent Notes: The Story of My Journey Round the World. A. Tsendina (ed.). Ser.: Mongolia. Collected Written Sources. History. Hohhot: Inner Mongolia Pedagogical Press, 2017. 133 p. (In Mong.)

Drobyshev Yu. I. Climate and Khans: Impact of the Climatic Factor on Central Asian Political History. Moscow: Institute of Oriental Studies (RAS), 2018. 264 p. (In Russ.)

Drobyshev Yu. I. Man and Nature in Central Asian Nomadic Communities: $3^{\text {rd }}$ Century BC $-14^{\text {th }}$ Century AD. D. Vasilyev, L. Lebedeva (eds.). Institute of Oriental Studies (RAS). Moscow: MBA, 2014. 605 p. (In Russ.)

Golman M. I. Contemporary Mongolia: Perspectives from the West. Moscow: Institute of Oriental Studies (RAS), 2010. 190 p. (In Russ.)

Golman M. I. Mongolia in the Eyes of a Mongolist: 1960-1970s. Moscow: Institute of Oriental Studies (RAS), 2019. 285 p. (In Russ.)

Golman M. I. Selected Articles and Reports. Ulaanbaatar: Soembo, 2014. 322 p. (In Russ.)

Grayvoronskiy V. V. (comp., ed.) B. Shirendyb and S. D. Dylykov in Memoirs by Their Relatives, Colleagues, and Friends: Celebrating $100^{\text {th }}$ Anniversaries of Births. Moscow: Institute of Oriental Studies (RAS), 2014. 192 p. (In Russ.)

Grayvoronskiy V. V. Changes in the Social Standard of Living in Buryatia (Russia), Mongolia and Inner Mongolia (China) at the End of 20 - Beg. of 21 Cent. Institute of Oriental Studies (RAS). Los Angeles; Ulaanbaatar: Agiymaa, 2014. 284 p. (In Russ.)

Grayvoronskiy V. V. Mongolia in the Early $21^{\text {st }}$ Century: Policy, Economy, Society. Moscow: Institute of Oriental Studies (RAS), 2017. 352 p. (In Russ.)

History of the Erdeni Zuu Monastery (Erdeni juuyin teüke). A. Tsendina (ed.). Ser.: Mongolia. Collected Written Sources. History. Hohhot: Inner Mongolia Pedagogical Press, 2017.276 p. (In Mong.)

History of the Zakhchin Buddhist Monastery. K. Orlova (foreword, transl., etc.). Moscow: Institute of Oriental Studies (RAS), 2012. 202 p. (In Russ. and Mong.)

Jamsrangjab. Diluwa Khutugtu in Mongolia: Political Memoirs and Autobiography of a Buddhist Reincarnate Hierarch. S. Kuzmin (ed.). Moscow: Save Tibet Foundation, 2018. 352 p. (In Russ.)

Kadyrbaev A. Sh. Yuán Shř as a source on the history of Keraites and Naimans. In: Written Monuments of the Orient. Studies in History and Philology. 1976-1977. Moscow: Nauka, GRVL, 1984. Pp. 254-259. (In Russ.)

Katasonova E. L. An undeclared war - the $75^{\text {th }}$ anniversary of the events at Khalkhin Gol. In: Kistanov V. O. et al. (eds.) Topical Issues of Contemporary Japan. Vol. XXVIII. Moscow: Institute of Far Eastern Studies (RAS), 2014. Pp. 189-200. (In Russ.)

Katasonova E. L. Japanese POWs in the USSR: 1945-1956. Collected Documents. Co-authored by V. Gavrilov. Moscow: Demokratiya, 2013. 779 p. (In Russ.)

Katasonova E. L. Khalkhin Gol: 70 years later. In: Japan 2009. Yearbook. Moscow: Institute of Oriental Studies (RAS), 2009. Pp. 271-293. (In Russ.)

Kitinov B. U. Buddhist Factor in Political and Ethnic History of the Oirats: 1450s to 1771. Dr.Sc. (history) thesis abstract. Moscow, 2020. 53 p. (In Russ.)

Kuzmin S. L. Mongolia: Theocratic State and Buddhist Church in the Early $20^{\text {th }}$ Century. Moscow: KMK, 2016. 496 p. (In Russ.)

Kuzmin S. L., Oyuunchimeg Zh. 1932 Armed Rebellion in Mongolia. Moscow: Institute of Oriental Studies (RAS); MBA, 2015. 138 p. (In Russ.)

Orlova K. V. (comp.), Grayvoronskiy V. V. (ed.) Mongolian Studies in Russia. Vol. 6. Moscow: Institute of Oriental Studies (RAS), 2012. 281 p. (In Russ.)

Orlova K. V. (comp., ed.), Grayvoronskiy V. V. (ed.) Vladimirtsov Readings - VI. Moscow: Institute of Oriental Studies (RAS), 2017. 272 p. (In Russ.)

Orlova K. V. Christianization of Kalmyks in the Context of Russia's Internal and External Policies: Mid-17 $7^{\text {th }}$ to Early $20^{\text {th }}$ Centuries. Moscow: Institute of Oriental Studies (RAS), 2018. 400 p. (In Russ.)

Orlova K. V., Grayvoronskiy V. V., Naumkin V. V. (eds.) Federal Security Service Archives: Mongolia Documented, 1922-1936. Moscow: Institute of Oriental Studies (RAS), 2019. 528 p. (In Russ.)

Roshchin S. K. D. Sükhbaatar - National Hero of Mongolia. Strokes to the Portrait. Ulaanbaatar: Selenge Press, 2011. 280 p. (In Russ. and Mong.)

Russia - Mongolia: History, Challenges of the $21^{\text {st }}$ Century, and Perspectives. Celebrating the $95^{\text {th }}$ Anniversary of Diplomatic Relations between Russia and Mongolia. Conference Proceedings (Moscow; October 13-14, 2016). Institute of 
Oriental Studies (RAS); Institute of History and Archaeology (Mongolian Academy of Sciences); Institute of Sociology (RAS) Ulaanbaatar: Admon, 2017. 250 p. (In Russ. and Mong.)

Rybakov R. B., Khaisandai L. (eds.) Russia and Mongolia: Towards Strategic Partnership. Institute of Oriental Studies (RAS); Institute of International Studies (Mongolian Academy of Sciences). Moscow: Institute of Oriental Studies (RAS), 2011. 440 p. (In Russ.)

Slesarchuk G. I. Articles of Different Years. S. Chuluun, K. Orlova, A. Tsendina (eds.). Ulaanbaatar: Soembo Printing, 2013. 220 p. (In Russ. and Mong.)

Sultanov T. I., Syzdykova Zh. S., Kadyrbaev A. Sh., Zaytsev I. V. History of Central Asia. Vol. 1. $2^{\text {nd }}$ ed., suppl. Moscow: Moscow University for the Humanities, 2015. 360 p. (In Russ.)

The Yellow Annals (Shar Tuuj). A. Tsendina (translit., transl. etc.). Facsimile A. Ser.: Written Monuments of the Orient. Vol. CXLVII. Moscow: Nauka; Vostochnaya Literatura, 2017. 406 p. (In Russ. and Mong.)

Timokhin D. M. Genghis Khan's Rival: Khwarazm Shah Jalal ad-Din Mingburnu, Personality and His Era. A. Kadyrbaev (ed.). Moscow: MBA, 2013. 268 p. (In Russ.)
Tsendina A. D., Otgonbaatar R. Examples of Northern Mongolia's Written Tradition: Alphabets, Transcriptions, Languages. $17^{\text {th }}-19^{\text {th }}$ Centuries. Moscow: Institute of Oriental Studies (RAS), 2014. 240 p. (In Russ.)

Vasilyev D. D. (comp.) Orhun: Atlas of Mongolia's Antiquities Published by V. V. Radlov. D. Vasilyev (transl., foreword). Ankara: TIKA, 1995. 80 p. (In Turk.)

Vasilyev D. D. Corpus of Turkic Runic Monuments from the Yenisei River Basin. Moscow: Nauka. 1983. 128 p. (In Russ.)

Vasilyev D. D. Khentii 1: Turkic runic inscription. Sovetskaya etnografiya. 1978. No. 3. Pp. 149151. (In Russ.)

Vasilyev D. D., Gorelik M. V., Klyashtorny S. G. States of Eurasian nomads: shaping imperial cultures. In: Valeeva-Suleimanova G. F. et al. (eds.) The Golden Horde. Glimpses of History. Kazan: Sultangaliev Foundation, 1993. Pp. 3344. (In Russ.)

Vladimirtsov B. Ya. Letters. The Unpublished. G. Slesarchuk, A. Tsendina (comps.); A. Tsendina (ed.). Moscow: Nauka; Vostochnaya Literatura, 2016. 390 p. (In Russ.)

Zheleznyakov A. S. Mongolian Civilization: Past and Present. Theoretical Rationales for the Atlas. Moscow: Ves Mir, 2016. 288 p. (In Russ.) 